\title{
Dentate Granule Cell Neurogenesis Is Increased by Seizures and Contributes to Aberrant Network Reorganization in the Adult Rat Hippocampus
}

\author{
Jack M. Parent, ${ }^{1}$ Timothy W. Yu, ${ }^{2}$ Rebecca T. Leibowitz, ${ }^{1}$ Daniel H. Geschwind, ${ }^{3}$ Robert S. Sloviter, ${ }^{4}$ and \\ Daniel H. Lowenstein ${ }^{1,2}$ \\ 1 Departments of Neurology and Anatomy, and ${ }^{2}$ Graduate Program in Neuroscience, University of California, San \\ Francisco, California 94143, ${ }^{3}$ Department of Neurology, University of California, Los Angeles, California 90024, \\ 4 Neurology Research Center, Helen Hayes Hospital, West Haverstraw, New York 10993, and Departments of \\ Pharmacology and Neurology, Columbia University, New York, New York 10032
}

The dentate granule cell layer of the rodent hippocampal formation has the distinctive property of ongoing neurogenesis that continues throughout adult life. In both human temporal lobe epilepsy and rodent models of limbic epilepsy, this same neuronal population undergoes extensive remodeling, including reorganization of mossy fibers, dispersion of the granule cell layer, and the appearance of granule cells in ectopic locations within the dentate gyrus. The mechanistic basis of these abnormalities, as well as their potential relationship to dentate granule cell neurogenesis, is unknown. We used a systemic chemoconvulsant model of temporal lobe epilepsy and bromodeoxyuridine (BrdU) labeling to investigate the effects of prolonged seizures on dentate granule cell neurogenesis in adult rats, and to examine the contribution of newly differentiated dentate granule cells to the network changes seen in this model. Pilocarpine-induced status epilepticus caused a dramatic and prolonged increase in cell proliferation in the dentate subgranular proliferative zone (SGZ), an area known to contain neuronal precursor cells. Colocalization of BrdU-immunolabeled cells with the neuron-specific markers turned on after division, $64 \mathrm{kDa}$, class III $\beta$-tubulin, or microtubule-associated protein-2 showed that the vast majority of these mitotically active cells differentiated into neurons in the granule cell layer. Newly generated dentate granule cells also appeared in ectopic locations in the hilus and inner molecular layer of the dentate gyrus. Furthermore, developing granule cells projected axons aberrantly to both the CA3 pyramidal cell region and the dentate inner molecular layer. Induction of hippocampal seizure activity by perforant path stimulation resulted in an increase in SGZ mitotic activity similar to that seen with pilocarpine administration. These observations indicate that prolonged seizure discharges stimulate dentate granule cell neurogenesis, and that hippocampal network plasticity associated with epileptogenesis may arise from aberrant connections formed by newly born dentate granule cells.

Key words: hippocampus; dentate granule cells; neurogenesis; pilocarpine; seizures; epilepsy; mossy fiber sprouting; network reorganization; synaptic plasticity
Among the principal neuronal populations within the hippocampal formation, the dentate granule cells have the unusual property of prolonged postnatal neurogenesis (Altman and Das, 1965, 1967; Gueneau et al., 1982; Eckenhoff and Rakic, 1988) that persists into adulthood in the rodent (Kaplan and Hinds, 1977; Bayer and Yackel, 1982; Kaplan and Bell, 1984; Cameron et al., 1993b; Seki and Arai, 1993; Kuhn et al., 1996). In the adult rat, neuronal precursors reside in the SGZ of the dentate gyrus, where they proliferate and migrate continuously into the granule cell layer (Cameron et al., 1993b; Seki and Arai, 1993; Kuhn et al.,

\footnotetext{
Received Nov. 2, 1996; revised Feb. 11, 1997; accepted Feb. 27, 1997.

This project was sponsored by the Epilepsy Foundation of America with support from the Burroughs Wellcome Fund and National EpiFellows Foundation award to J.M.P., National Institutes of Health (NIH) Grant NS01849 and a McDonnell-Pew Program in Cognitive Neuroscience Grant to D.H.G., NIH Grant NS18201 to R.S.S., and NIH Grants NS32062 and NS35628 and a Klingenstein Fellowship in the Neurosciences to D.H.L. We thank Dr. S. Hockfield for providing TOAD-64 antibody, Dr. V. Lee for providing NF-M antibody, and Dr. A. Frankfurter for providing TuJ1 antibody. We also thank R. Messing for assistance in confocal microscopy, and E. Cooper, H. Scharfman, and R. Messing for critical review of this manuscript.

Correspondence should be addressed to Daniel H. Lowenstein, Department of Neurology, Box 0114, University of California, San Francisco, San Francisco, CA 94143-0114.

Copyright (C) 1997 Society for Neuroscience $\quad 0270-6474 / 97 / 173727-12 \$ 05.00 / 0$
}

1996). There they develop granule cell morphology (Kaplan and Hinds, 1977; Kaplan and Bell, 1984; Cameron et al., 1993b; Seki and Arai, 1993), express markers of differentiated neurons (Cameron et al., 1993b; Okano et al., 1993; Kuhn et al., 1996), and extend axonal processes to their postsynaptic targets (Stanfield and Trice, 1988; Seki and Arai, 1993). The extent to which the continuous birth of granule cells influences or maintains the network properties of the normal hippocampal formation is unknown.

In addition to their distinctive developmental profile, dentate granule cells are thought to play a central role in the pathogenesis of temporal lobe epilepsy, one of the most common human seizure disorders (Houser, 1992; Manford et al., 1992; Weiser et al., 1993; Engel, 1996). Although hippocampi from some patients with temporal lobe epilepsy exhibit granule cell loss (Houser, 1990; O'Connor et al., 1996), the granule cell layer is preserved in most cases (Bruton, 1988; Houser, 1992; Meldrum and Bruton, 1992). Often, the surviving granule cell layer is dispersed, and ectopic granule neurons are found in the hilus and inner molecular layer (Houser, 1990, 1992). Furthermore, the dentate granule cells give rise to abnormal axonal projections to the supragranular inner molecular layer of the dentate gyrus. This process, described 
as mossy fiber "sprouting," can be identified by Timm staining of zinc in mossy fiber terminals or by dynorphin immunohistochemistry (de Lanerolle et al., 1989; Sutula et al., 1989; Houser et al., 1990; Babb et al., 1991). In addition to sprouting in the dentate inner molecular layer, aberrant reorganization of mossy fibers to the basal dendrites of CA3 pyramidal cells in stratum oriens has also been observed in rodents after electrical kindling (Represa and Ben-Ari, 1992; Van der Zee et al., 1995).

The precise mechanisms and functional consequences of seizure-induced mossy fiber reorganization remain to be defined. Mossy fiber remodeling has been attributed to collateral sprouting of axons from preexisting, mature dentate granule cells (Represa and Ben-Ari, 1992; Isokawa et al., 1993; Franck et al., 1995; Okazaki et al., 1995). Ultrastructural and electrophysiological studies of mossy fiber sprouting into the inner molecular layer suggest that this synaptic reorganization may result in recurrent excitatory circuits and subsequent hippocampal hyperexcitability (Tauck and Nadler, 1985; Cronin and Dudek, 1988; Cronin et al., 1992; Isokawa et al., 1993; Franck et al., 1995; Okazaki et al., 1995; Wuarin and Dudek, 1996). It has also been proposed, however, that aberrant granule cell axonal projections stabilize the network by preferentially innervating inhibitory neurons and thereby restoring recurrent inhibition (Sloviter, 1992).

The temporal and spatial coexistence of dentate granule cell neurogenesis and seizure-induced hippocampal network reorganization in adult rodents raises the possibility of a relationship between these two phenomena. Importantly, indirect evidence from human temporal lobe autopsy and surgical specimens suggests that human dentate granule cell neurogenesis may continue into early childhood (Seress, 1992; Mathern et al., 1994, 1996), a time when cerebral insults can initiate temporal lobe epileptogenesis (Sagar and Oxbury, 1987; Marks et al., 1992; Kuks et al., 1993; Harvey et al., 1995). Given the data on continuing granule cell neurogenesis, we hypothesized that hippocampal network plasticity associated with chronic seizures is derived primarily from newly born granule neurons rather than from preexisting, mature dentate granule cells.

To examine this hypothesis, we combined bromodeoxyuridine (BrdU) mitotic labeling and confocal double-label fluorescence immunohistochemistry using neuron- or glia-specific markers to assess cell proliferation and fate in the adult rat dentate gyrus after pilocarpine-induced status epilepticus. The pilocarpine seizure model replicates many of the features observed in human temporal lobe epilepsy, including an initial episode of prolonged status epilepticus followed by spontaneous, recurrent seizures, and temporal lobe pathology similar to that seen in the human (Cavalheiro et al., 1991; Mello et al., 1993). Immunohistochemical staining using antibodies to the neuron-specific, early postmitotic marker turned on after division, $64 \mathrm{kDa}$ (TOAD-64) (Minturn et al., 1995a,b), or to mid-sized neurofilament protein (NF-M) (Pleasure et al., 1990), was also performed to determine the pattern of axon outgrowth from newly differentiated dentate granule cells in pilocarpine-treated animals. Last, we examined whether SGZ mitotic activity could be altered by perforant path stimulation that induced hippocampal seizure discharges for a duration associated with little or no neuronal loss. Our results demonstrate that seizure activity produces a marked increase in dentate granule cell neurogenesis, and that newly differentiated dentate granule cells contribute to abnormal hippocampal network plasticity in experimental temporal lobe epilepsy.

\section{MATERIALS AND METHODS}

Seizure induction. For pilocarpine-induced status epilepticus experiments, adult male Sprague Dawley rats (200-250 gm) were pretreated with injections of atropine methylbromide $(5 \mathrm{mg} / \mathrm{kg}$, i.p.) (Sigma, St. Louis, $\mathrm{MO})$ and $15 \mathrm{~min}$ later were given pilocarpine hydrochloride (320-350 $\mathrm{mg} / \mathrm{kg}$, i.p.) (Sigma). Seizure activity was monitored behaviorally, and after $3-5 \mathrm{hr}$ of convulsive status epilepticus, seizures were terminated with diazepam $(10 \mathrm{mg} / \mathrm{kg}$, i.p.) (Elkins-Sinn, Cherry Hill, NJ). Only rats that displayed continuous, convulsive seizure activity after pilocarpine treatment were used in these experiments. Control rats received saline and diazepam injections only. The methods for perforant path stimulation have been described in detail (Sloviter, 1983; Sloviter et al., 1996). Briefly, adult male Sprague Dawley rats were anesthetized with ether and then given urethane $(1.25 \mathrm{gm} / \mathrm{kg}$, s.c.; $250 \mathrm{mg}$ urethane/ml saline). Bipolar stainless steel stimulating electrodes (NE-200, Rhodes Medical) were placed in the angular bundle, and continuous stimulation at $2 \mathrm{~Hz}$ (paired pulses $40 \mathrm{msec}$ apart) with intermittent $10 \mathrm{sec}$ trains of single stimuli delivered at $20 \mathrm{~Hz}$ (once per minute) was maintained for $6(n=6)$ or 24 hr $(n=4)$. Control animals included rats that were implanted but not stimulated $(n=5)$, and naive rats $(n=4)$.

BrdU labeling. Rats were given a single series of four injections of $\mathrm{BrdU}$ $(50 \mathrm{mg} / \mathrm{kg}$, i.p., dissolved in PBS) (Boehringer Mannheim, Indianapolis, IN) every $2 \mathrm{hr}$ during a period of $6 \mathrm{hr}$ to label mitotically active cells. For time course experiments, animals received BrdU 1, 3, 6, 13, or $27 \mathrm{~d}$ after pilocarpine ( $n=3-5$ animals per group) or saline treatment $(n=5)$, and were killed $24 \mathrm{hr}$ after BrdU administration, except for the $1 \mathrm{~d}$ group, which was killed 1-4 hr after the last BrdU injection. Two animals were also injected with BrdU 1 year after pilocarpine and killed $1 \mathrm{~d}$ later. For perforant path stimulation studies, BrdU was administered $6 \mathrm{~d}$ after the end of electrical stimulation, and the animals were killed $24 \mathrm{hr}$ later. For all other experiments, animals received BrdU on day 7 after pilocarpine ( $n=3$ per time point $)$ or saline ( $n=1$ per time point $)$ administration and were killed 7, 14, or $28 \mathrm{~d}$ later. An additional two pilocarpine-treated animals received BrdU on day 7 and were killed on day 60 after pilocarpine administration.

Tissue fixation, immunohistochemistry, and Timm staining. After an anesthetic overdose, all animals were transcardially perfused as follows: normal saline ( $3 \mathrm{~min}) ; 2 \%$ paraformaldehyde in $0.1 \mathrm{M}$ sodium acetate, $\mathrm{pH}$ 6.5 (3 $\mathrm{min})$; and $2 \%$ paraformaldehyde $/ 0.1 \%$ glutaraldehyde in $0.1 \mathrm{M}$ borate, $\mathrm{pH} 8.5$ (20-30 min). Rats surviving for $14 \mathrm{~d}$ or longer were also perfused with $0.37 \%$ sulfide solution, $\mathrm{pH} 7.2$ (5 min), before aldehydes for subsequent Timm staining. After post-fixation in situ overnight, brains were removed and placed in Tris buffer $(0.1 \mathrm{M}, \mathrm{pH}$ 7.6). Coronal, vibratome sections ( $40 \mu \mathrm{m}$ thick) were then obtained and placed in Tris buffer for immunohistochemistry or immunofluorescence, or were stored in cryoprotectant [ $30 \%$ ethylene glycol and $30 \%$ sucrose $(\mathrm{w} / \mathrm{v})$ in $0.5 \mathrm{M}$ phosphate buffer, $\mathrm{pH} 7.2]$ at $-20^{\circ} \mathrm{C}$ until they were processed.

Immunohistochemistry was performed on coronal, free-floating sections through the septotemporal extent of the hippocampus. For BrdU immunostaining, DNA was first denatured by incubating tissue sections in 50\% formamide $/ 2 \times \operatorname{SSC}(0.3 \mathrm{M} \mathrm{NaCl}, 0.03 \mathrm{M}$ sodium citrate), and then $2 \mathrm{~N} \mathrm{HCl}$, as described by Kuhn et al. (1996). Sections were then rinsed three times for 5 min each in Tris buffer $\left(0.1 \mathrm{M}, \mathrm{pH}\right.$ 7.6) and treated with $1 \% \mathrm{H}_{2} \mathrm{O}_{2}$ to block endogenous peroxidase. After they were washed for $15 \mathrm{~min}$ each in Tris A $(0.1 \mathrm{M}$ Tris buffer $/ 0.1 \%$ Triton $\mathrm{X}-100)$ and Tris B ( $0.1 \mathrm{~m}$ Tris buffer, $0.1 \%$ Triton X-100, $0.05 \%$ BSA), sections were placed in $10 \%$ normal horse serum or normal goat serum in Tris B for $1 \mathrm{hr}$. The sections were then incubated with primary antibody (diluted in Tris B) to BrdU (mouse monoclonal, 1:1000; Boehringer Mannheim) or proliferating cell nuclear antigen (PCNA) (mouse monoclonal, 1:100; Boehringer Mannheim) overnight at room temperature, or to TOAD-64 (rabbit polyclonal, 1:30,000; a gift of Dr. Susan Hockfield, Yale University) for $36 \mathrm{hr}$ at $4^{\circ} \mathrm{C}$. After $15 \mathrm{~min}$ rinses in Tris A and Tris $\mathrm{B}$, sections were incubated with biotinylated secondary antibody (1:200 dilution in Tris B; Vector Laboratories, Burlingame, CA) for $45 \mathrm{~min}$, washed again in Tris A and Tris B for 15 min each, and then incubated for $1 \mathrm{hr}$ in avidin-biotin-peroxidase complex (Vectastain Elite ABC, Vector). After three washes ( 5 min each) in Tris buffer, reaction product was detected using $0.05 \%$ 3,3'-diaminobenzidine-tetrahydrochloride (DAB; Sigma) in a solution containing $20 \mathrm{ml}$ of $0.1 \mathrm{M}$ Tris buffer, $20 \mu \mathrm{l}$ of $3 \mathrm{mg} / \mathrm{ml}$ glucose oxidase, $160 \mu \mathrm{l}$ of $250 \mathrm{mg} / \mathrm{ml}$ D-glucose, and $40 \mu \mathrm{l}$ of $200 \mathrm{mg} / \mathrm{ml}$ ammonium chloride. For double-labeling, sections were first stained with anti-BrdU antibody using avidin-biotin-alkaline phosphatase (Vectastain ABC-AP, Vector) and reacted to form a red substrate (Vector) after incubation with $1 \mathrm{~mm}$ levamisol (Sigma) to block endogenous alkaline phosphatase. This was followed by four brief washes in Tris buffer, a second blocking step (10\% 
normal horse serum in Tris B), an $8 \mathrm{hr}$ incubation with anti-NF-M antibody (mouse monoclonal RMO270.7, 1:10,000 dilution; gift of Dr. Virginia Lee, University of Pennsylvania) at room temperature, and detection as a brown substrate with the DAB reaction described above. The specificity of immunolabeling was verified in all experiments by controls in which the primary antibody was omitted.

To assess patterns of mossy fiber growth, Timm staining was performed on hippocampal sections from all pilocarpine-treated and control animals killed 14 or more days after treatment, according to the method of Sloviter (1982). Mossy fiber sprouting to the inner molecular layer was confirmed by Timm staining in all pilocarpine-treated rats and was not seen in controls.

Immunofluorescence and confocal microscopy. For double-label immunofluorescence, free-floating sections were first denatured by incubation in $2 \mathrm{~N} \mathrm{HCl}$ for $30 \mathrm{~min}$ at $37^{\circ} \mathrm{C}$, washed in boric acid $(0.1 \mathrm{M}, \mathrm{pH} 8.5)$ for 10 min, and rinsed several times with Tris buffer $(0.1 \mathrm{M}, \mathrm{pH} 7.6)$. After treatment for $1 \mathrm{hr}$ in Tris-buffered saline $(0.15 \mathrm{M} \mathrm{NaCl}, 0.1 \mathrm{M}$ Tris- $\mathrm{HCl}$, $\mathrm{pH} 7.6)$ containing $10 \%$ normal goat serum and $0.4 \%$ Triton $\mathrm{X}-100$, sections were incubated overnight at room temperature with primary antibody to BrdU (rat monoclonal, 1:50 dilution; Accurate Chemical, Westbury, NY) and to class III $\beta$-tubulin (TuJ1, mouse monoclonal, 1:400 dilution; a gift of Dr. Anthony Frankfurter, University of Virginia), vimentin (mouse monoclonal, 1:50 dilution; DAKO, Carpinteria, CA), glial fibrillary acidic protein (GFAP; rabbit polyclonal, 1:200 dilution; Sigma), or microtubule-associated protein-2 (MAP2) (mouse monoclonal, 1:500 dilution; Sigma). After several rinses in Tris buffer and a second blocking step, sections were incubated for $1 \mathrm{hr}$ with goat secondary antibody (1:200 dilution) conjugated to fluorescein isothiocyanate (antirat; Jackson Immunoresearch Laboratories, West Grove, PA), Cy5 (antimouse; Jackson), Texas Red (anti-rabbit; Molecular Probes, Eugene, $\mathrm{OR}$ ), or Cy3 (anti-rabbit; Jackson). Sections were then rinsed and mounted in anti-fade medium (ProLong, Molecular Probes). For BrdU/ TOAD-64 double-labeling, tissue sections were incubated in primary antibody to TOAD-64 (1:10,000 dilution) for $36 \mathrm{hr}$ at $4^{\circ} \mathrm{C}$, washed twice in Tris buffer, and incubated for $45 \mathrm{~min}$ with biotinylated goat anti-rabbit secondary antibody (Vector). After several washes in Tris buffer, sections were processed by the alkaline phosphatase reaction to form a red substrate (visible with both light and epifluorescence microscopy) and then for BrdU immunofluorescence as described above. Immunofluorescence images were obtained using a BioRad MRC 600 or MRC 1024 confocal laser microscope as Z-series stacks and analyzed for colocalization of staining using National Institutes of Health Image v 1.6 software.

Quantification and statistical analyses. For BrdU-labeling time course experiments in pilocarpine- or saline-treated rats, mounted sections spaced at least $160 \mu \mathrm{m}$ apart were subjected to blinded densitometric analysis via a digital image analysis system and National Institutes of Health Image v 1.6 software. Six to nine sections per animal (12-18 hippocampi) divided between the anterior, middle, and posterior thirds of the hippocampus were analyzed for BrdU immunostaining in an area encompassing the entire granule cell layer (superior and inferior blades), and extending approximately two cell layer widths deep into the hilus (SGZ). Small BrdU-labeled nuclei (presumed to be glial precursors) at the hilar border and linear (endothelial-like) immunostained forms were excluded from the analysis. The mean percentage of area stained was determined for each group, and ANOVA with Fisher's protected least significant difference (PLSD) post hoc test was performed using StatView software (Abacus Concepts, Berkeley, CA). To validate the densitometric analysis, numbers of BrdU-immunostained nuclei per dentate granule cell layer from three control and five treated animals were manually scored by a blinded examiner. The results were highly correlated with the automated analysis. Measurements of BrdU labeling in the $6 \mathrm{hr}$ perforant path stimulation and control groups were performed using the same densitometric analysis technique, and differences were assessed for statistical significance by paired Student's $t$ test using StatView software (Abacus).

\section{RESULTS}

\section{Pilocarpine-induced status epilepticus increases cell proliferation in the SGZ of the adult dentate gyrus}

To examine the potential effects of prolonged seizures on granule cell neurogenesis and synaptic reorganization, we first used pilocarpine to induce status epilepticus in adult rats and then administered systemic BrdU to label mitotically active cells. Consistent with previous reports (Seki and Arai, 1993; Kuhn et al., 1996), BrdU immunohistochemistry in control rats, performed $1 \mathrm{~d}$ after a series of BrdU injections spanning $6 \mathrm{hr}$, labeled a small number of clustered nuclei located in the SGZ (Fig. 1A,B). These sections had isolated clusters of BrdU-immunoreactive (IR), irregularly shaped nuclei extending from the hilar border into the inner granule cell layer. In contrast, pilocarpine-induced status epilepticus caused a marked increase (six- to eightfold) in BrdU incorporation in the SGZ (Fig. 1C,D). Clusters were more numerous and larger, and in some cases they formed a nearly contiguous layer along the granule cell/hilus border. No qualitative differences in BrdU immunostaining were noted between sections obtained from the anterior, middle, or posterior hippocampal regions in controls or pilocarpine-treated rats.

Quantitative analysis of BrdU labeling within the SGZ and dentate granule cell layer revealed a significant increase in mitotic activity 3,6 , and $13 \mathrm{~d}$ after pilocarpine compared with controls (Fig. 1E). The number of BrdU-labeled cells in the SGZ returned to baseline by $27 \mathrm{~d}$ after the initial seizures and was lower than baseline levels in two animals examined 1 year later. Although the amount of BrdU uptake in different hippocampal regions was relatively constant within individual animals, there was some variability in the amount of increase in mitotic labeling between animals from a given time point after status epilepticus; however, none of the 14 pilocarpine-treated rats that were BrdU-labeled between 3 and $13 \mathrm{~d}$ after seizures displayed the control pattern of BrdU immunostaining. In addition, immunocytochemistry using antibodies to PCNA, a G1 and S-phase cell cycle marker (Miyachi et al., 1978; Mathews et al., 1984; Minturn et al., 1995b), showed comparable changes in the pattern of SGZ mitotic activity in pilocarpine-treated versus control rats (Fig. $1 F, G$ ). Numerous small, BrdU-immunolabeled nuclei were observed at early time points after pilocarpine treatment (i.e., 1 and $3 \mathrm{~d}$ ) in the hilus, CA3 and CA1 pyramidal cell regions, neocortex, and other brain regions (data not shown), consistent with glial proliferation in areas of damage that has been demonstrated previously in models of chemoconvulsant-induced injury (Altar and Baudry, 1990; Morshead and van der Kooy, 1990; Niquet et al., 1994).

\section{Seizure activity increases neurogenesis in the adult dentate granule cell layer}

We next examined the long-term fate of mitotically active cells in the dentate gyrus by injecting BrdU $7 \mathrm{~d}$ after pilocarpine or saline treatment (i.e., within the period of significantly increased mitosis) and then killing the animals 7-28 d later. BrdU immunostaining revealed a progressive dispersion of labeled cells throughout the granule cell layer of pilocarpine-treated animals that was substantially greater than that seen in controls (Fig. $1 \mathrm{H}, \mathrm{I}$ ). At these later time points, BrdU-immunostained nuclei in the granule cell layer were larger than in the presumed SGZ progenitor cells and had a more rounded appearance characteristic of mature granule cells. In addition, more variability in the intensity of BrdU immunostaining was apparent. This may represent a dilution of incorporated BrdU in cells undergoing multiple divisions, analogous to the dilution of tritiated thymidine labeling observed in a previous study of dentate granule cell neurogenesis (Cameron et al., 1993b). Alternatively, some of the variability may be accounted for by differences in the specific point within S-phase at which the labeled cells were exposed to BrdU (Miller and Nowakowski, 1988). The ratio of BrdU-immunostaining within the granule cell layer versus the SGZ increased at later time points, supporting previous observations of apparent migration of neu- 

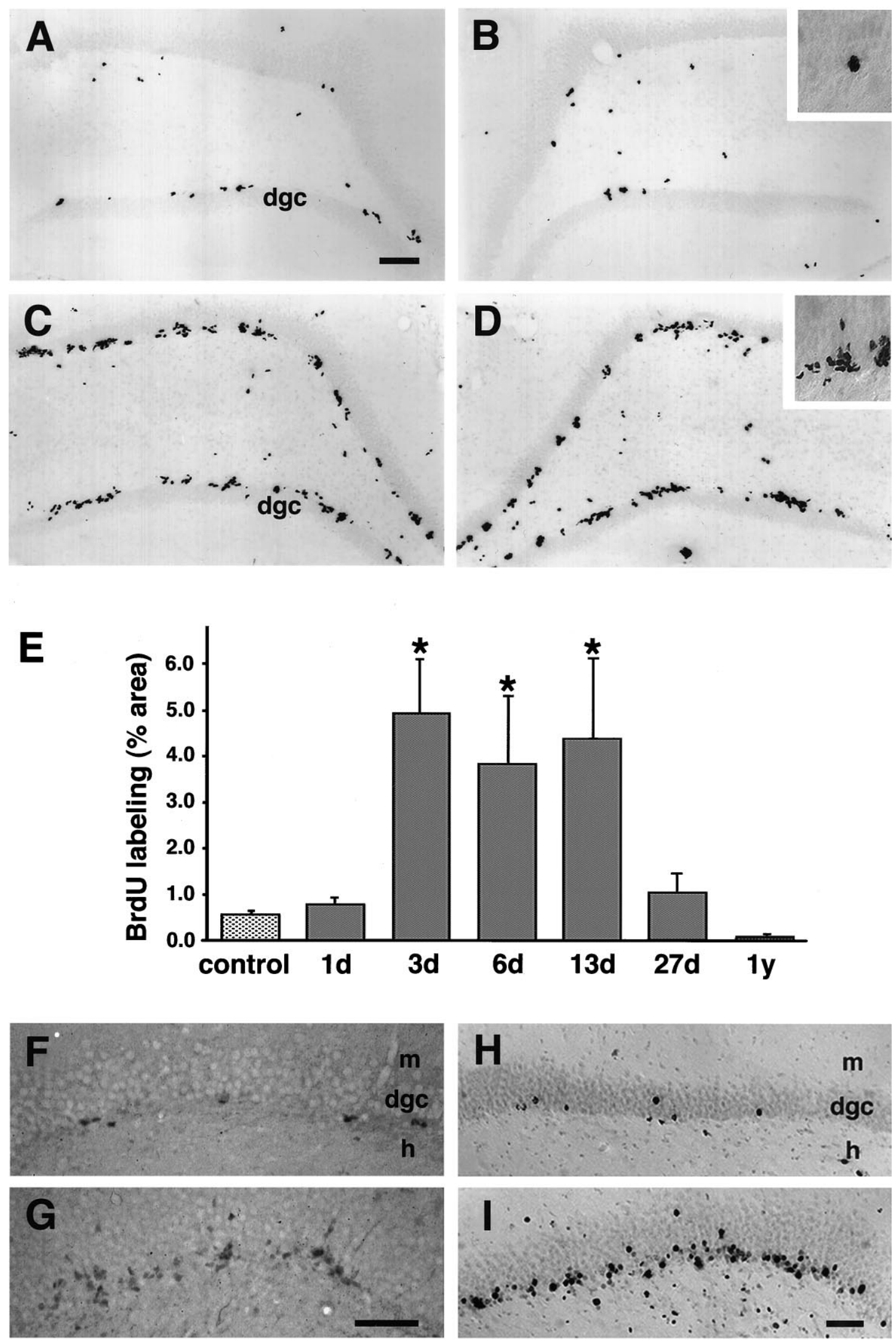

Figure 1. Upregulation of cell proliferation in the adult dentate gyrus after status epilepticus. $A, B$, Baseline mitotic activity in the dentate gyrus of a saline-treated control rat identified by BrdU labeling and immunohistochemistry. $C, D$, Increased dentate SGZ BrdU incorporation $13 \mathrm{~d}$ after pilocarpine-induced status epilepticus. Note the clustering of BrdU-IR nuclei in the SGZ at the border of the hilus and granule cell layer (insets in $B$ and $D$ ). In both animals, BrdU immunohistochemistry was performed $24 \mathrm{hr}$ after the animal received four intraperitoneal injections of $50 \mathrm{mg} / \mathrm{kg}$ BrdU over $6 \mathrm{hr}$. E, Proliferative activity in the dentate SGZ and granule cell layer was significantly increased at $3 \mathrm{~d}$, remained elevated at (Figure legend continues) 
roblasts into the granule cell layer (Cameron et al., 1993b; Seki and Arai, 1993; Kuhn et al., 1996). BrdU-labeled cells survived for at least $53 \mathrm{~d}$ (the longest period evaluated) when animals were given BrdU on day 7 and killed on day 60 after the initial seizures (data not shown).

The neuronal identity of newly generated cells within the granule cell layer was established by cellular colocalization of BrdU with neuron-specific markers. Animals that received BrdU $7 \mathrm{~d}$ after pilocarpine treatment were killed 7, 14, or 28 d later, and fluorescence double-label immunocytochemistry was performed. Confocal microscopic analysis demonstrated colocalization of BrdU-IR nuclei within cells (Fig. $2 A-C$ ) labeled by antibodies against the neuron-specific, early differentiation marker class III $\beta$-tubulin (Lee et al., 1990; Easter et al., 1993; Minturn et al., 1995b) or TOAD-64 (Minturn et al., 1995a,b; Wang and Strittmatter, 1996), as well as the differentiated neuronal marker MAP2 (Bernhardt and Matus, 1984; Huber and Matus, 1984). Of 59 BrdU-labeled nuclei in the granule cell layer, 52 were immunoreactive for class III $\beta$-tubulin ( $7 \mathrm{~d}$ after BrdU administration). Similarly, 40 of 45 were double-labeled with BrdU and TOAD-64 (14 d after BrdU), and 33 of 38 were double-labeled with BrdU and MAP2 (28 d after BrdU). In contrast, the astrocytic markers vimentin (Schnitzer et al., 1981; Pixley and De Vellis, 1984; Schiffer et al., 1986) and GFAP (Latov et al., 1979; Debus et al., 1983) rarely colocalized with BrdU-immunostained nuclei in the granule cell layer (none of 41 nuclei for vimentin and 4 of 37 for GFAP $14 \mathrm{~d}$ after BrdU administration) (Fig. 2D), despite the presence of BrdU/vimentin-positive and BrdU/GFAP-positive cells in the neighboring dentate hilus and other brain regions (data not shown). These results demonstrate that seizures increase neurogenesis in the dentate granule cell layer.

\section{Newly generated dentate granule cells display ectopic migration patterns and aberrant mossy fiber organization after seizures}

We next sought to determine whether any of the characteristic pathological changes seen in temporal lobe epilepsy might derive from newly born granule cells. To examine this question, we took advantage of the fact that TOAD-64 is expressed in cell bodies and processes of early postmitotic neurons (Minturn et al., 1995a,b). TOAD-64, also known as collapsin response mediator protein-2 (CRMP-2), is a member of the CRMP family that is putatively involved in axonal guidance during development (Wang and Strittmatter, 1996). As expected, TOAD-64-IR cells in the hippocampi of control animals were found along the hilar border of the dentate granule cell layer (Fig. $3 A$ ). The finding of an increase in granule cell neurogenesis in pilocarpine-treated animals predicted an elevation in the number of TOAD-64-IR dentate granule cells. In fact, a change in the number of TOAD-64-IR cells, as well as the intensity of TOAD-64 labeling, was evident 1 week after seizures and was markedly increased $28 \mathrm{~d}$ after pilocarpine (Fig. 3B). By $60 \mathrm{~d}$ after pilocarpine, no qualitative differ- ence in TOAD-64 staining was noted between treated versus control animals (data not shown).

TOAD-64-IR cells that exhibited morphological features of mature granule cells were found in ectopic locations within the dentate gyrus of pilocarpine-treated rats. Although the majority of labeled cells resided at the base of the granule cell layer, TOAD64-IR cells also appeared within the hilus and in the most superficial portions of the granule cell layer, extending into the inner molecular layer (Fig. 3C-E). Despite their ectopic location, these cells demonstrated the morphological characteristics of dentate granule cells, with dendrite-like arbors reaching the molecular layer, and axon-like processes entering the mossy fiber pathway. In contrast, TOAD-64-IR cells in control animals were never seen in the dentate hilus or the inner molecular layer. These observations suggest that the normal migration pattern of newly generated dentate granule cells from the SGZ to the inner granule cell layer was altered by the pilocarpine treatment.

In addition to changes in the number and distribution of TOAD-64-immunolabeled cell bodies, the pattern of TOAD64-IR mossy fibers was abnormal in pilocarpine-treated rats. Many of the newly formed granule cell axons seemed to follow anomalous trajectories (Fig. $3 B$ ). A marked increase in TOAD64-IR processes was found in the stratum oriens of the CA3 pyramidal cell region, and these fibers colocalized with "sprouted" mossy fiber axons identified with the Timm stain (Fig. 4A-D). TOAD-64-IR mossy fiber-like processes were also seen to traverse the granule cell layer into the inner molecular layer of the dentate gyrus, and thin processes within the inner molecular layer were oriented parallel to the granule cell layer (Fig. $4 E$ ); however, because TOAD-64 is also expressed in postmitotic granule cell dendrites, precise identification of the mossy fiber-like processes as axons in the dentate granule cell and molecular layers cannot be regarded as definitive.

To establish whether granule cells born after pilocarpineinduced status epilepticus sent axons into the inner molecular layer, we performed double-label immunocytochemistry with antibodies to BrdU and the neuronal cytoskeleton antigen NF-M (Pleasure et al., 1990). In animals injected with BrdU on day 7 post-pilocarpine and killed on day 35, neurons in the granule cell layer with BrdU-IR nuclei were seen to extend NF-M-labeled axonal processes that curved back into the granule cell layer to reach the inner molecular layer (Fig. $4 F, G$ ), an abnormal location for dentate granule cell axons.

\section{Pure electrical activation increases cell proliferation in the adult dentate gyrus}

The previous results indicate that pilocarpine-induced status epilepticus leads to increased dentate granule cell neurogenesis in adult rats; however, pilocarpine causes widespread seizure activity, widespread neuronal injury, and various systemic alterations (Cavalheiro et al., 1991; Mello et al., 1993). To separate the effects of seizure discharges per se from the

\section{$\leftarrow$}

6 and $13 \mathrm{~d}$, and returned to baseline levels by $27 \mathrm{~d}$ after pilocarpine treatment. Proliferative activity is represented as a percentage of the area labeled by BrdU-immunostaining in the SGZ and dentate granule cell layer (mean \pm SEM), as determined by quantitative densitometric analysis. Asterisks denote statistically significant differences from controls $(p<0.05$; ANOVA with Fisher's PLSD post hoc test). $F, G$, PCNA immunostaining in the dentate gyrus of adult rats $4 \mathrm{~d}$ after saline $(F)$ or pilocarpine treatment $(G)$ demonstrated an increase in dentate SGZ mitotic activity after pilocarpine-induced status epilepticus similar to that seen with BrdU labeling. $H, I$, Delayed BrdU immunostaining in the dentate gyrus of control $(H)$ and pilocarpine-treated $(I)$ adult rats revealed a separation of labeled nuclei that were previously clustered (see $B, D$ ), and increased numbers of labeled nuclei that appear to have migrated further into the granule cell layer, especially in the pilocarpine-treated animal. BrdU was administered on day 7 after saline injection or pilocarpine-induced status epilepticus, and immunohistochemistry was performed 4 weeks later. Scale bars: $A-D, 100 \mu \mathrm{m} ; F-I, 50 \mu \mathrm{m}$. $d g c$, Dentate granule cell layer; $m$, molecular layer; $h$, hilus. 

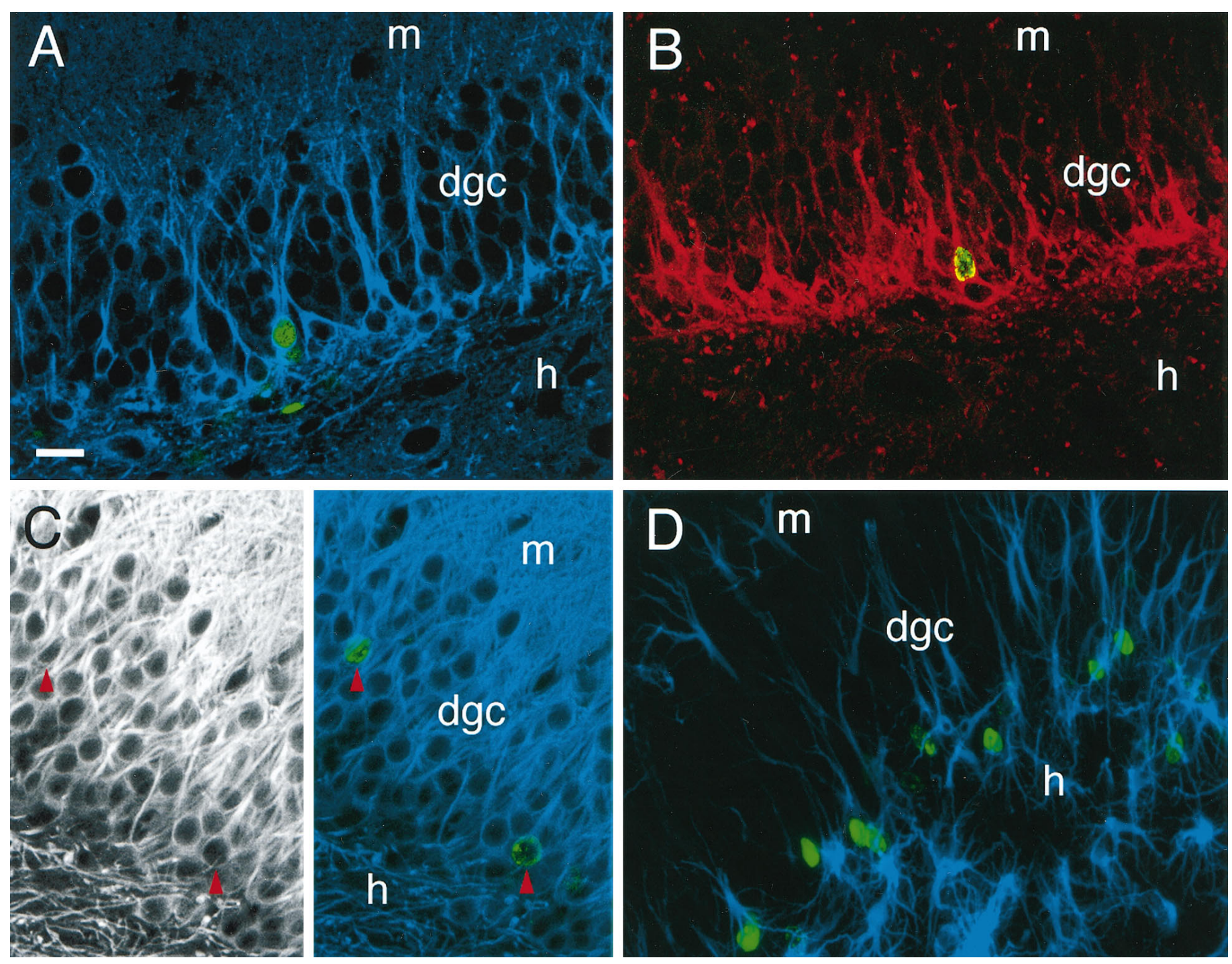

Figure 2. Neuronal phenotype of BrdU-labeled cells in the dentate granule cell layer after pilocarpine-induced status epilepticus. Animals received BrdU on day 7 after pilocarpine treatment and were killed 7, 14, or $28 \mathrm{~d}$ later. A, Nuclear BrdU immunoreactivity (green) colocalized with immunostaining using TuJ1 (blue), a monoclonal antibody against the neuron-specific marker class III $\beta$-tubulin, in animals killed $7 \mathrm{~d}$ after BrdU injection. Neuron-specific $\beta$-tubulin is expressed in early postmitotic and differentiated neurons, and in some mitotically active neuronal precursors. $B$, Nuclear BrdU-IR (green) was seen within cells immunostained for TOAD-64 (red) $14 \mathrm{~d}$ after BrdU injection. TOAD-64 is a membraneassociated marker expressed in the cell bodies and processes of newly born, but not adult, neurons. Note that most of the TOAD-64-IR cells are BrdU-negative because of the abbreviated availability of BrdU for incorporation into S-phase cells after a $6 \mathrm{hr}$ injection period, as compared with the more prolonged accumulation of newly postmitotic TOAD-IR neurons. C, Left panel, Immunofluorescence using antibodies to MAP2 labeled cell bodies and dendrites of dentate granule neurons in an adult rat $28 \mathrm{~d}$ after BrdU administration (and 35 days after pilocarpine). Right panel, In the same section, BrdU-IR (green) colocalized with immunostaining for MAP2 (blue) (red arrowheads indicate colocalization). Note that double-labeled cells in $A-C$ possess characteristic dentate granule cell morphology (medium-sized nuclei with round or oval-shaped cell bodies, and dendrites extending into the molecular layer). $D$, In contrast to colocalization of BrdU with neuronal markers, BrdU-IR ( green) rarely colocalized with the astrocytic markers vimentin (blue) or GFAP (not shown). $A-C$ are $1 \mu \mathrm{m}$ optical sections obtained by confocal microscopy to resolve antibody localization within individual cells. $D$ is a composite of 19 stacked optical sections. Scale bar (shown in $A$ ): $25 \mu \mathrm{m}$. $d g c$, Dentate granule cell layer; $h$, hilus; $m$, molecular layer.

numerous effects of pilocarpine as potential stimuli for SGZ mitotic activity, we used perforant path stimulation to elicit focal hippocampal seizures in adult rats. With this method, the degree of cell injury can be controlled by altering the duration of stimulation (Sloviter, 1983; Sloviter and Lowenstein, 1992; Sloviter et al., 1996). Animals underwent $6 \mathrm{hr}$ of continuous perforant path stimulation, a duration that results in little or no hilar or pyramidal neuron injury (Fig. $5 A, B, E, F$ ), as reported previously (Sloviter and Lowenstein, 1992). BrdU labeling (Fig. $5 C, D, G, H)$ in stimulated animals $(n=6)$ revealed a significant increase in dentate SGZ and granule cell layer mitotic activity 6 d later compared with sham electrode controls $(n=6)$ (mean increase of $163 \% ; p=0.04)$. A similar increase in BrdU labeling was seen in animals stimulated for $24 \mathrm{hr}(n=4$; data not shown), a duration that causes hippocampal injury (Sloviter, 1983; Sloviter et al., 1996). These results suggest that prolonged, focal seizure discharges are sufficient to increase mitotic activity in the precursor population of the adult SGZ in the absence of prolonged motor seizures, widespread injury, or convulsant drug effects. 

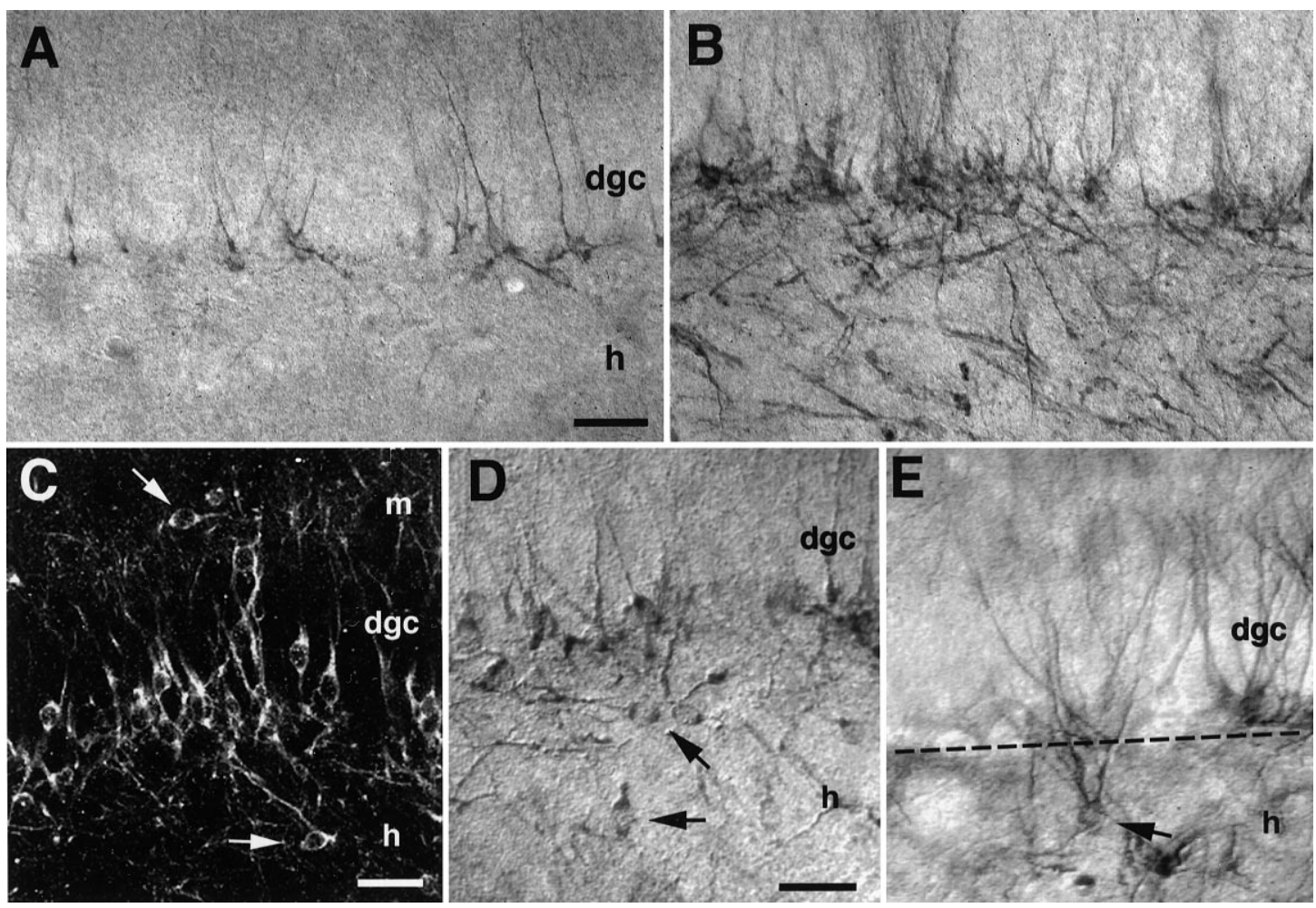

Figure 3. Status epilepticus alters the location of newly born granule cell bodies and their processes. Immunocytochemistry with antibodies to the neuron-specific, early postmitotic marker TOAD-64 revealed newly differentiating neurons in the granule cell layer $(d g c)$ of adult rats $28 \mathrm{~d}$ after saline $(A)$ or pilocarpine $(B)$ administration. The number of TOAD-64-immunostained cells increased after status epilepticus, and many TOAD-64immunolabeled processes exhibited a disorganized pattern that was not seen in controls. $C-E$, In pilocarpine-treated but not control rats, many immunolabeled cell bodies with the size and shape of granule cells were found in the inner molecular layer (arrow in $C$ ) or in the hilus (arrows in $C-E$ ). Note in $E$ the presence of a TOAD-64-IR cell in the hilus with a soma and dendritic arbor characteristic of a dentate granule cell, yet ectopically located $\sim 50 \mu \mathrm{m}$ from the $d g c$. The dotted line demarcates the DGC/hilar border. Scale bars: $A, B, 100 \mu \mathrm{m} ; C-E, 40 \mu \mathrm{m}$. $d g c$, Dentate granule cell layer; $h$, hilus; $m$, molecular layer.

\section{DISCUSSION}

The two key findings of this study are that prolonged seizure activity markedly increases neurogenesis in the dentate gyrus of adult rats and that newly born dentate granule cells contribute to hippocampal network reorganization in the pilocarpine model of temporal lobe epilepsy. Previous studies have provided evidence that dentate granule cell neurogenesis continues at a low level in the adult rat hippocampal formation (Kaplan and Hinds, 1977; Bayer and Yackel, 1982; Kaplan and Bell, 1984; Cameron et al., 1993b; Seki and Arai, 1993; Kuhn et al., 1996) and that these neurons appear to add to the existing granule cell population (Bayer and Yackel, 1982; Crespo et al., 1986). Our observations indicate that in the setting of pilocarpine-induced hippocampal seizures and neuronal injury, progenitor cells in the SGZ are stimulated to proliferate. A substantial portion of these cells migrate into the granule cell layer, display a neuronal phenotype, and develop morphological characteristics of differentiated dentate granule cells. Furthermore, we found that cell proliferation in the SGZ was stimulated by hippocampal seizure activity produced by intermittent perforant path stimulation that does not induce significant neuronal injury (Sloviter and Lowenstein, 1992). This suggests that relatively restricted seizure activity is sufficient to upregulate dentate granule cell neurogenesis.

Several lines of evidence support the idea that the seizureinduced increases in BrdU labeling observed in the present study represent uptake of BrdU into mitotically active progenitor cells and not into nuclei of injured, mature neurons. First, except for smaller labeled nuclei that appeared with a time course and localization consistent with injury-induced glial proliferation, increased dentate gyrus BrdU labeling (in animals examined within $1 \mathrm{~d}$ of BrdU injection) was confined to clusters of nuclei in the SGZ and deep dentate granule cell layer at the hilar border. This locus of mitotic activity was the same as that seen in uninjured controls and the same as that reported previously (Seki and Arai, 1993; Kuhn et al., 1996). Second, BrdU incorporation also remained elevated for as long as $13 \mathrm{~d}$ after status epilepticus, a time when ongoing widespread injury is unlikely. The majority of BrdU-immunostained nuclei dispersed progressively and were found further within the granule cell layer over time, features most consistent with migration of progenitor cells from the SGZ. Furthermore, PCNA, an independent marker of mitotic activity, was also upregulated in the SGZ after seizures.

The concept that granule cell neurogenesis is markedly increased after seizure activity is supported by the results of the immunohistochemical studies using antibodies to TOAD-64. The elevation of SGZ BrdU labeling induced by pilocarpine treatment preceded an increase in the number of TOAD-64-IR neurons in the interior granule cell layers, consistent with the notion of progenitor cell proliferation and subsequent neuronal differentiation and migration. The altered pattern of TOAD-64 immunostaining after seizures likely represents its expression in newly postmitotic, rather than mature, neurons for several reasons. There were no changes in TOAD-64 immunoreactivity in the hippocampal formation within the first week after initial seizures, 


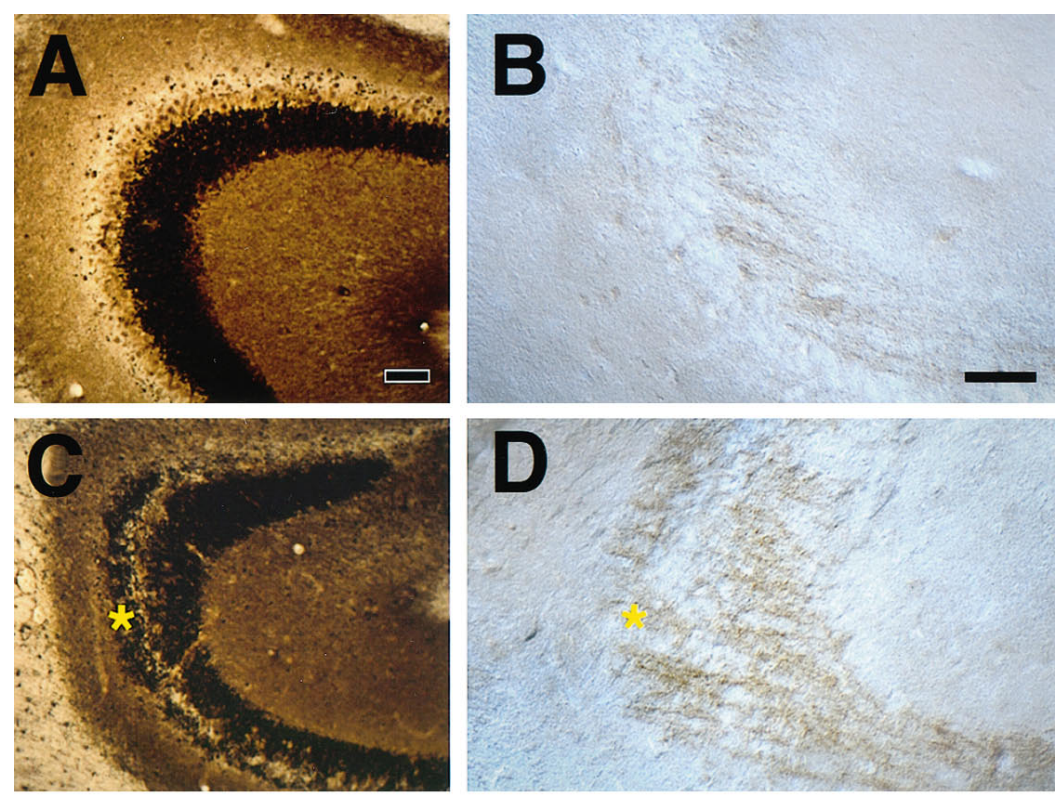

Figure 4. Status epilepticus leads to a disruption of normal patterns of newly born granule cell axon outgrowth. $A, C$, Timm staining of sections from the mid-portion of the hippocampus. Pilocarpine-treated rats demonstrated dense, aberrant reorganization of granule cell mossy fiber terminals into the stratum oriens of the CA3 pyramidal cell region in pilocarpine-treated rats (asterisk in $C$ ). This was not typically seen in controls $(A)$, except for occasional mild-to-moderate staining in anterior hippocampal regions. TOAD-64 immunolabeling of similar hippocampal regions in the same control $(B)$ and pilocarpinetreated $(D)$ animals confirmed that the sprouting involved the outgrowth of TOAD-64-immunostained mossy fibers derived from newly postmitotic dentate granule cells (asterisk in $D$ ). $E$, Evidence for the presence of aberrant axons from newly born granule cells in the inner molecular layer of pilocarpine-treated animals. Within the molecular layer, TOAD-IR fibers were seen oriented perpendicular to the normal dendritic pattern of staining (arrowheads). The coexistence of immunoreactive dendrites prohibited the identification of these perpendicular processes as axons. $F$, $G$, Double-label immunohistochemistry using antibodies to BrdU and NF-M provided direct evidence for newborn cells sending aberrant axons into the molecular layer. Yellow arrowheads denote BrdU-labeled nuclei of the cells of origin; black arrowheads delineate the trajectory of the NF-M-stained axons. Note the presence of an axonal branch oriented toward the hilus (arrow, $G$ ). Scale bar: $A-D, 100 \mu \mathrm{m} ; E, 50 \mu \mathrm{m} ; F, G, 25$ $\mu \mathrm{m} . d g c$, Dentate granule cell layer; $h$, hilus; $m$, molecular layer.
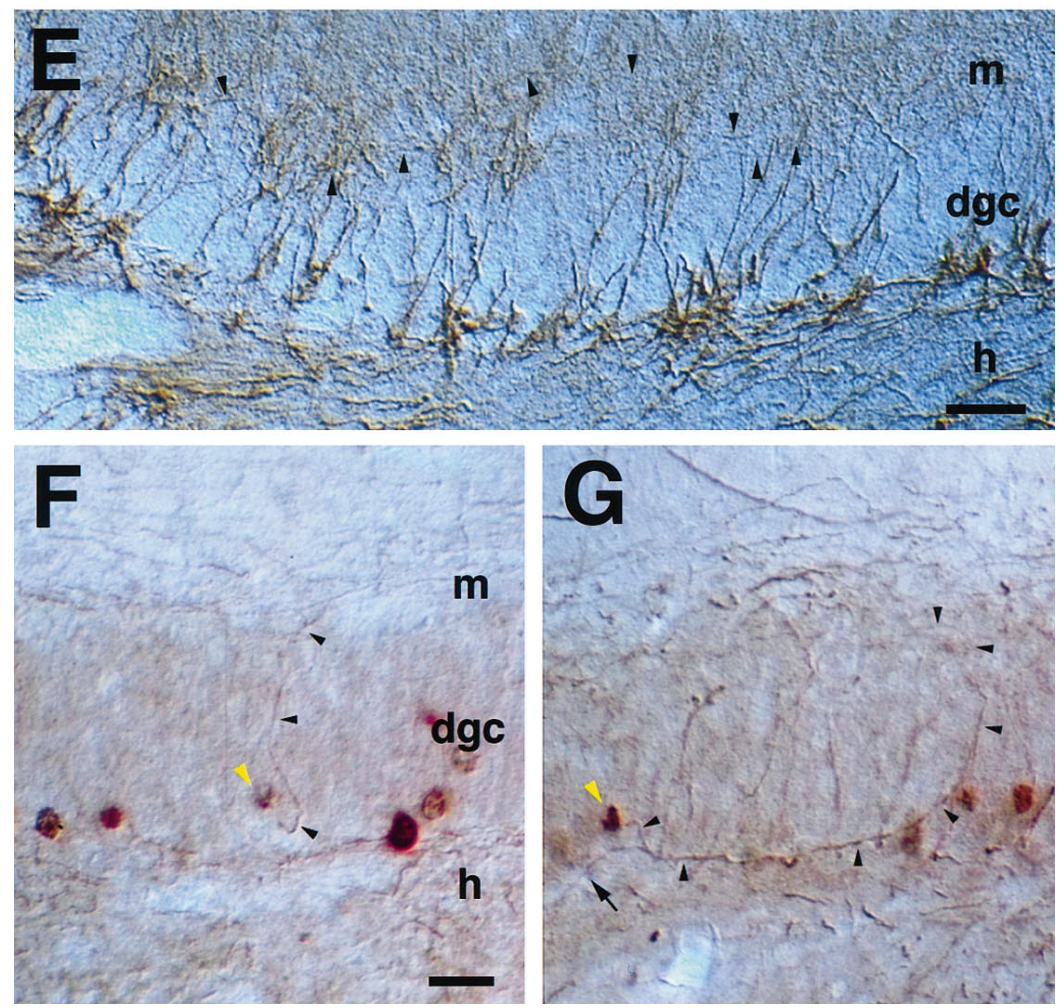

and TOAD-64-IR cells were not observed in other injured brain regions at any time. Moreover, except for a small number of neurons exhibiting granule cell morphology in the hilus or molecular layer, TOAD-64 immunostaining was restricted mainly to cells in the inner aspect of the dentate granule cell layer, as in controls.

In addition to increasing dentate granule cell neurogenesis, pilocarpine-induced status epilepticus in adult rats seems to cause abnormalities of dentate granule cell development. Our experimental findings suggest that these newly born neurons contribute to the hippocampal pathology seen in human temporal lobe epilepsy. TOAD-64-IR neurons with granule cell morphology were found in unusual locations, i.e., the dentate hilus and inner molecular layer, the same regions in which "ectopic" granule neuron-like cells have been identified in surgical specimens from humans with temporal lobe epilepsy (Houser, 1990; Sloviter et al., 1991). Although the precise origin of these cells is unknown, their appearance after pilocarpine treatment, but not in controls, suggests that they migrated aberrantly from the SGZ. Our observations of an increase in large BrdU-immunolabeled nuclei in the hilus with increasing time after BrdU administration provide support for the idea that these cells are migrating to, rather than arising from, the hilus.

Along with the presence of ectopically located TOAD-64immunolabeled cell bodies, we also found that mossy fiber-like processes elaborated by newly generated neurons in the gran- 


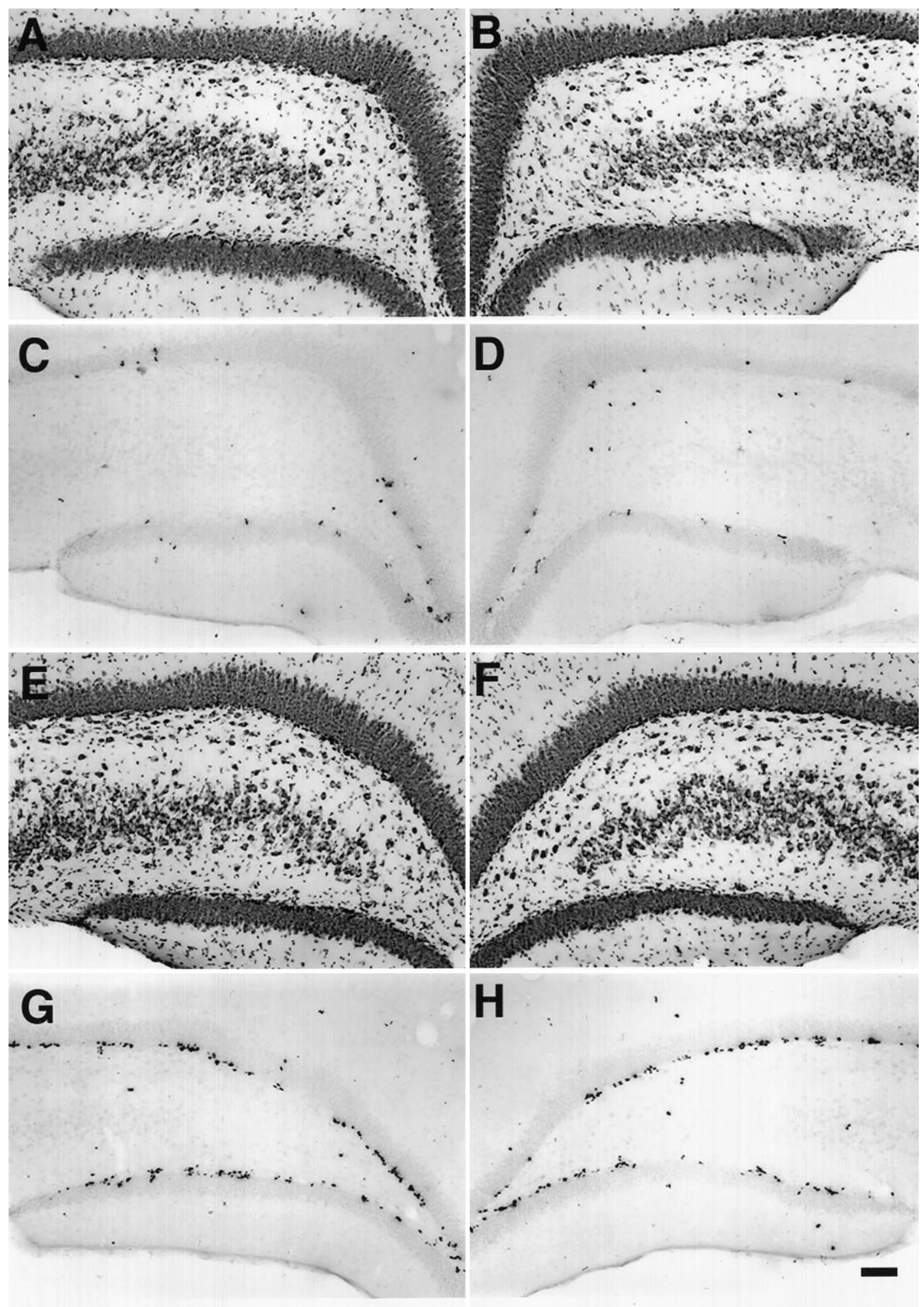

Figure 5. $A, B$, Nissl-stained dentate gyrus of a sham-stimulated animal showing normal structure on the side contralateral $(A)$ and ipsilateral $(B)$ to electrode placement. $C, D$, BrdU labeling in the same sham control animal. BrdU was injected $6 \mathrm{~d}$ after the end of $6 \mathrm{hr}$ sham stimulation, and the animal was killed $1 \mathrm{~d}$ after BrdU administration. $E, F$, Nissl-stained dentate gyrus after $6 \mathrm{hr}$ perforant path stimulation. Note the relatively normal histological structure after this duration of stimulation, which produces little or no damage. $G, H$, BrdU labeling of sections from the same animal showing that 6 hr of stimulation increased BrdU labeling in the SGZ bilaterally, similar to the pattern of BrdU-IR seen after pilocarpine treatment (Fig. 1C,D). The mean \pm SEM of \% area BrdU labeled in the SGZ and dentate granule cell layer was $0.69 \pm 0.19$ for controls $(n=6)$ and $1.81 \pm 0.53$ for stimulated animals $(n=$ 6). Scale bar, $100 \mu \mathrm{m}$. 
ule cell layer are disorganized within the hilus and project to atypical regions, including stratum oriens of area CA3 and the inner molecular layer of the dentate gyrus. These findings therefore provide the first direct evidence that abnormal hippocampal network formation in rodent models of temporal lobe epilepsy involves aberrant axon outgrowth that arises from newly born dentate granule cells. Further studies are needed to determine whether mossy fiber sprouting consists entirely of aberrant axonogenesis or a combination of neurogenesis and remodeling of preexisting axons; however, it is noteworthy that chemoconvulsant-induced mossy fiber sprouting to the inner molecular layer is known to begin within 1-2 weeks after status epilepticus and increases progressively over several months (Lowenstein et al., 1993; Mello et al., 1993). This time course parallels our observations of a prolonged increase in dentate granule cell neurogenesis after seizures, taking into account the additional time required for subsequent differentiation of these cells into mature neurons (Cameron et al., 1993b; Okano et al., 1993). Because increased dentate SGZ cell proliferation also occurs after durations of perforant path stimulation that produces little or no cell loss and little or no mossy fiber reorganization to the dentate inner molecular layer (R. S. Sloviter, unpublished observations), it is likely that other factors related to chemoconvulsant treatment, such as loss of input to the molecular layer or widespread hippocampal injury, are required to produce aberrant mossy fiber network remodeling.

The occurrence of seizure-induced neurogenesis and survival of newly differentiated neurons also raises a number of new and intriguing questions. First, what are the cellular mechanisms by which seizures stimulate mitotic activity in the adult SGZ? SGZ precursor cells seem to be modulated to lesser degrees by alterations of excitatory amino acid transmission (Gould et al., 1994; Cameron et al., 1995), deafferentation of the granule cell layer (Cameron et al., 1995), and indirectly by adrenal steroids (Gould et al., 1992; Cameron et al., 1993a). Some mitotically active SGZ precursor cells seem to receive synaptic contacts (Kaplan and Bell, 1983, 1984), raising the possibility that seizures stimulate neurogenesis by direct synaptic activation. Cell death, which has been proposed to stimulate neurogenesis in the olfactory bulb (Graziadei et al., 1979; Schwartz Levey et al., 1991; Carr and Farbman, 1992), and which occurs in the hippocampus in human and experimental epilepsy, may act separately or in concert with seizure activity to increase the birth rate of dentate granule cells. Recent studies suggest that dentate granule cells are susceptible to various forms of injury, including adrenalectomy (Sloviter et al., 1989; Gould and McEwen, 1993) and prolonged seizures (Sloviter et al., 1996). Increased hippocampal neurogenesis after seizures may therefore be an adaptive response to a degree of granule cell death previously unrecognized in the pilocarpine seizure model.

Second, how does status epilepticus result in aberrant cell migration and process outgrowth of differentiating granule neurons? Newly born dentate granule cells seem to migrate appropriately and integrate into existing circuits in the normal adult hippocampal formation (Kaplan and Bell, 1983, 1984; Stanfield and Trice, 1988; Cameron et al., 1993b; Seki and Arai, 1993). Prolonged seizure activity may disrupt migration via alterations in excitatory neurotransmission or neuronal calcium influx, because these mechanisms have been demonstrated to play a role in neuronal migration during normal development (Komuro and Rakic, 1993; Rakic and Komuro, 1995). On the other hand, others have proposed that glial cues are important in hippocampal reorganization induced by seizures (Represa et al., 1995). Perhaps perturbations of the glial architecture alter normal cell migration and axonal pathfinding of these newly born cells.

Abnormal hippocampal plasticity of dentate granule cells and their axonal connections is a prominent feature of human temporal lobe epilepsy (de Lanerolle et al., 1989; Sutula et al., 1989; Houser et al., 1990; Babb et al., 1991). Although the contributions of granule cell neurogenesis to seizure-induced network reorganization in the human remain entirely unexplored, the most distinctive characteristics of the newly born neuronal population shown in this experimental study-migration to ectopic locations and formation of aberrant axonal projections-parallel some of the key pathological abnormalities seen in the dentate gyrus of patients with temporal lobe epilepsy (Houser, 1990, 1992). Temporal lobe epilepsy often has its onset during childhood or is associated with a prolonged seizure episode early in life that is followed, after a variable latent period, by the development of epilepsy (Sagar and Oxbury, 1987; Marks et al., 1992; Kuks et al., 1993; Harvey et al., 1995). Indirect evidence from human temporal lobe surgical and autopsy specimens indicates that dentate granule cell neurogenesis may continue postnatally at least into early childhood (Seress, 1992; Mathern et al., 1994, 1996), and mossy fiber sprouting is known to occur in infants and children with focal epilepsies (Represa et al., 1993; Mathern et al., 1994, 1996). Thus, our findings lead us to hypothesize that differentiation of a population of newly born granule cells, rather than remodeling of mature granule cells, is the basis for the network reorganization seen in some forms of human temporal lobe epilepsy.

\section{REFERENCES}

Altar CA, Baudry M (1990) Systemic injection of kainic acid: gliosis in olfactory and limbic brain regions quantified with $\left[{ }^{3} \mathrm{H}\right] \mathrm{PK} 11195$ binding autoradiography. Exp Neurol 109:333-341.

Altman J, Das GD (1965) Autoradiographic and histological evidence of postnatal hippocampal neurogenesis in rats. J Comp Neurol 124:319-335.

Altman J, Das GD (1967) Postnatal neurogenesis in the guinea pig. Nature 214:1098-1101.

Babb TL, Kupfer WR, Pretorious JK, Crandall PH, Levesque MF (1991) Synaptic reorganization by mossy fibers in human epileptic fascia dentata. Neuroscience 42:351-363.

Bayer SA, Yackel JW (1982) Neurons in the rat dentate gyrus granular layer substantially increase during juvenile and adult life. Science 216:890-892.

Bernhardt R, Matus A (1984) Light and electron microscopic studies of the distribution of microtubule-associated protein 2 in rat brain: a difference between dendritic and axonal cytoskeletons. J Comp Neurol 226:203-221.

Bruton CJ (1988) The neuropathology of temporal lobe epilepsy. Oxford: Oxford UP.

Cameron HA, Woolley CS, Gould E (1993a) Adrenal steroid receptor immunoreactivity in cells born in the adult rat dentate gyrus. Brain Res 611:342-346.

Cameron HA, Woolley CS, McEwen BS, Gould E (1993b) Differentiation of newly born neurons and glia in the dentate gyrus of the adult rat. Neuroscience 56:337-344.

Cameron HA, McEwen BS, Gould E (1995) Regulation of adult neurogenesis by excitatory input and NMDA receptor activation in the dentate gyrus. J Neurosci 15:4687-4692.

Carr VM, Farbman AI (1992) Ablation of the olfactory bulb up-regulates the rate of neurogenesis and induces precocious cell death in olfactory epithelium. Exp Neurol 115:55-59.

Cavalheiro EA, Leite JP, Bortolotto ZA, Turski WA, Ikonomidou C, Turski L (1991) Long-term effects of pilocarpine in rats: structural damage of the brain triggers kindling and spontaneous recurrent seizures. Epilepsia 32:778-782.

Crespo D, Stanfield BB, Cowan WM (1986) Evidence that lategenerated granule cells do not simply replace earlier formed neurons in the rat dentate gyrus. Exp Brain Res 62:541-548. 
Cronin J, Dudek FE (1988) Chronic seizures and collateral sprouting of dentate mossy fibers after kainic acid treatment in rats. Brain Res 474:181-184.

Cronin J, Obenaus A, Houser CR, Dudek FE (1992) Electrophysiology of dentate granule cells after kainate-induced synaptic reorganization of the mossy fibers. Brain Res 573:305-310.

Debus E, Weber K, Osborn M (1983) Monoclonal antibodies specific for glial fibrillary acidic (GFA) protein and for each of the neurofilament triplet polypeptides. Differentiation 25:193-203.

de Lanerolle NC, Kim JH, Robbins RJ, Spencer DD (1989) Hippocampal interneuron loss and plasticity in human temporal lobe epilepsy. Brain Res 495:387-395.

Easter SS, Ross LS, Frankfurter A (1993) Initial tract formation in the mouse brain. J Neurosci 13:285-299.

Eckenhoff MF, Rakic P (1988) Nature and fate of proliferative cells in the hippocampal dentate gyrus during the life span of the rhesus monkey. J Neurosci 8:2729-2747.

Engel Jr JE (1996) Surgery for seizures. New Engl J Med 334:647-652.

Franck JE, Pokorny J, Kunkel DD, Schwartzkroin PA (1995) Physiologic and morphologic characteristics of granule cell circuitry in human epileptic hippocampus. Epilepsia 36:543-558.

Gould E, McEwen BS (1993) Neuronal birth and death. Curr Opin Neurobiol 3:676-682.

Gould E, Cameron HA, Daniels DC, Woolley CS, McEwen BS (1992) Adrenal hormones suppress cell division in the adult rat dentate gyrus. J Neurosci 12:3642-3650.

Gould E, Cameron HA, McEwen BS (1994) Blockade of NMDA receptors increases cell death and birth in the developing rat dentate gyrus. J Comp Neurol 340:551-565.

Graziadei PPC, Levine RR, Monti Graziadei GA (1979) Plasticity of connections of the olfactory sensory neuron: regeneration into the forebrain following bulbectomy in the neonatal mouse. Neuroscience 4:713-727.

Gueneau G, Privat A, Drouet J, Court L (1982) Subgranular zone of the dentate gyrus of young rabbits as a secondary matrix: a high-resolution autoradiographic study. Dev Neurosci 5:345-358.

Harvey AS, Grattan-Smith JD, Desmond PM, Chow CW, Berkovic SF (1995) Febrile seizures and hippocampal sclerosis: frequent and related findings in intractable temporal lobe epilepsy of childhood. Pediatr Neurol 12:201-206.

Houser CR (1990) Granule cell dispersion in the dentate gyrus of humans with temporal lobe epilepsy. Brain Res 535:195-204.

Houser CR (1992) Morphological changes in the dentate gyrus in human temporal lobe epilepsy. In: The dentate gyrus and its role in seizures, Epilepsy Research [Suppl 7] (Ribak CE, Gall CM, Mody I, eds), pp 223-234. Amsterdam: Elsevier.

Houser CR, Miyashiro JE, Swartz BE, Walsh GO, Rich JR, DelgadoEscueta AV (1990) Altered patterns of dynorphin immunoreactivity suggest mossy fiber reorganization in human hippocampal epilepsy. J Neurosci 10:267-282.

Huber G, Matus A (1984) Differences in the cellular distributions of two microtubule-associated proteins, MAP1 and MAP2, in rat brain. J Neurosci 4:151-160.

Isokawa M, Levesque MF, Babb TL, Engel Jr J (1993) Single mossy fiber axonal systems of human dentate granule cells studied in hippocampal slices from patients with temporal lobe epilepsy. J Neurosci 13:1511-1522.

Kaplan MS, Bell DH (1983) Neuronal proliferation in the 9-month-old rodent: radioautographic study of granule cells in the hippocampus. Exp Brain Res 52:1-5.

Kaplan MS, Bell DH (1984) Mitotic neuroblasts in the 9-day-old and 11-month-old rodent hippocampus. J Neurosci 4:1429-1441.

Kaplan MS, Hinds JW (1977) Neurogenesis in adult rat: electron microscopic analysis of light radioautographs. Science 197:1092-1094.

Komuro H, Rakic P (1993) Modulation of neuronal migration by NMDA receptors. Science 260:95-97.

Kuhn HG, Dickinson-Anson H, Gage FH (1996) Neurogenesis in the dentate gyrus of the adult rat: age-related decrease of neuronal progenitor proliferation. J Neurosci 16:2027-2033.

Kuks JBM, Cook MJ, Fish DR, Stevens JM, Shorvon SD (1993) Hippocampal sclerosis in epilepsy and childhood febrile seizures. Lancet 342:1391-1394.

Latov N, Nilaver G, Zimmerman EA, Johnson WG, Silverman AJ, Defendini R, Cote L (1979) Fibrillary astrocytes proliferate in response to brain injury: a study combining immunoperoxidase technique for glial fibrillary acidic protein and radioautography of tritiated thymidine. Dev Biol 72:381-384.

Lee MK, Rebhun LI, Frankfurter A (1990) Posttranslational modification of class III $\beta$-tubulin. Proc Natl Acad Sci USA 87:7195-7199.

Lowenstein DH, Seren MS, Longo FM (1993) Prolonged increases in neurotrophic activity associated with kainate-induced hippocampal synaptic reorganization. Neuroscience 56:597-604.

Manford M, Hart YM, Sander JWAS, Shorvon SD (1992) National General Practice Study of Epilepsy (NGPSE): partial seizure patterns in a general population. Neurology 42:1911-1917.

Marks DA, Kim J, Spencer DD, Spencer SS (1992) Characteristics of intractable seizures following meningitis and encephalitis. Neurology 42:1513-1518.

Mathern GW, Leite JP, Pretorius JK, Quinn B, Peacock WJ, Babb TL (1994) Children with severe epilepsy: evidence of hippocampal neuron losses and aberrant mossy fiber sprouting during postnatal granule cell migration and differentiation. Dev Brain Res 78:70-80.

Mathern GW, Babb TL, Mischel PS, Vinters HV, Pretorius JK, Leite JP, Peacock WJ (1996) Childhood generalized and mesial temporal epilepsies demonstrate different amounts and patterns of hippocampal neuron loss and mossy fibre synaptic reorganization. Brain 119:965-987.

Mathews MB, Bernstein RM, Franza Jr BR, Garrels JI (1984) Identity of the proliferating cell nuclear antigen and cyclin. Nature 309:374-376.

Meldrum BS, Bruton CJ (1992) Epilepsy. In: Greenfield's neuropathology (Adams JH, Duchen LW, eds), pp 1246-1283. New York: Oxford UP.

Mello LE, Cavalheiro EA, Tan AM, Kupfer WR, Pretorius JK, Babb TL, Finch DM (1993) Circuit mechanisms of seizures in the pilocarpine model of chronic epilepsy: cell loss and mossy fiber sprouting. Epilepsia 34:985-995.

Miller MW, Nowakowski RS (1988) Use of bromodeoxyuridineimmunohistochemistry to examine the proliferation, migration and time of origin of cells in the central nervous system. Brain Res 457:44-52.

Minturn JE, Fryer HJL, Geschwind DH, Hockfield S (1995a) TOAD-64, a gene expressed early in neuronal differentiation in the rat, is related to unc-33, a C. elegans gene involved in axon outgrowth. J Neurosci 15:6757-6766.

Minturn JE, Geschwind DH, Fryer HJL, Hockfield S (1995b) Early postmitotic neurons transiently express TOAD-64, a neural specific protein. J Comp Neurol 355:369-379.

Miyachi K, Fritzler MJ, Tan EM (1978) Antibody to a nuclear antigen in proliferating cells. J Immunol 121:2228-2234.

Morshead CM, van der Kooy D (1990) Separate blood and brain origins of proliferating cells during gliosis in adult brains. Brain Res 535:237-244.

Niquet J, Ben-Ari Y, Represa A (1994) Glial reaction after seizure induced hippocampal lesion: immunohistochemical characterization of proliferating glial cells. J Neurocytol 23:641-656.

O'Connor WM, Masukawa L, Freese A, Sperling MR, French JA, O'Connor MJ (1996) Hippocampal cell distributions in temporal lobe epilepsy: a comparison between patients with and without an early risk factor. Epilepsia 37:440-449.

Okano HJ, Pfaff DW, Gibbs RB (1993) RB and cdc2 expression in brain: correlations with ${ }^{3} \mathrm{H}$-thymidine incorporation and neurogenesis. J Neurosci 13:2930-2938.

Okazaki MM, Evenson DA, Nadler JV (1995) Hippocampal mossy fiber sprouting and synapse formation after status epilepticus in rats: visualization after retrograde transport of biocytin. J Comp Neurol 352:515-534.

Pixley SK, de Vellis J (1984) Transition between immature radial glia and mature astrocytes studied with a monoclonal antibody to vimentin. Brain Res 317:201-209.

Pleasure SJ, Lee VM, Nelson DL (1990) Site-specific phosphorylation of the middle molecular weight human neurofilament protein in transfected non-neuronal cells. J Neurosci 10:2428-2437.

Rakic P, Komuro H (1995) The role of receptor/channel activity in neuronal cell migration. J Neurobiol 26:299-315.

Represa A, Ben-Ari Y (1992) Kindling is associated with the formation of novel mossy fibre synapses in the CA3 region. Brain Res 92:69-78.

Represa A, Robain O, Tremblay E, Ben-Ari Y (1993) Hippocampal plasticity in childhood epilepsy. Neurosci Lett 99:351-355.

Represa A, Niquet J, Pollard H, Ben-Ari Y (1995) Cell death, gliosis, and synaptic remodeling in the hippocampus of epileptic rats. J Neurobiol 26:413-425.

Sagar HJ, Oxbury JM (1987) Hippocampal neuron loss in temporal lobe 
epilepsy: correlation with early childhood convulsions. Ann Neurol 22:334-340.

Schiffer D, Giordana MT, Migheli A, Giaccone G, Pezzotta S, Mauro A (1986) Glial fibrillary acidic protein and vimentin in the experimental glial reaction of the rat brain. Brain Res 374:110-118.

Schnitzer J, Franke WW, Schachner M (1981) Immunocytochemical demonstration of vimentin in astrocytes and ependymal cells of developing and adult mouse nervous system. Cell Biol 90:435-447.

Schwarz Levey M, Chikaraishi DM, Kauer JS (1991) Characterization of potential precursor populations in the mouse olfactory epithelium using immunocytochemistry and autoradiography. J Neurosci 11:3556-3564.

Seki T, Arai Y (1993) Highly polysialylated neural cell adhesion molecule (NCAM-H) is expressed by newly generated granule cells in the dentate gyrus of the adult rat. J Neurosci 13:2351-2358.

Seress L (1992) Morphological variability and developmental aspects of monkey and human granule cells: differences between the rodent and primate dentate gyrus. In: The dentate gyrus and its role in seizures, Epilepsy Research [Suppl 7] (Ribak CE, Gall CM, Mody I, eds), pp 3-28. Amsterdam: Elsevier.

Sloviter RS (1982) A simplified Timm stain procedure compatible with formaldehyde fixation and routine embedding of rat brain. Brain Res Bull 8:771-774.

Sloviter RS (1983) "Epileptic" brain damage in rats induced by sustained electrical stimulation of the perforant path. I. Acute electrophysiological and light microscopic studies. Brain Res Bull 10:675-697.

Sloviter RS, Sollas AL, Barbaro NM, Laxer KD (1991) Calcium-binding protein (calbindin-D28K) and parvalbumin immunocytochemistry in the normal and epileptic human hippocampus. J Comp Neurol 308:381-396.

Sloviter RS (1992) Possible functional consequences of synaptic reorganization in the dentate gyrus of kainate-treated rats. Neurosci Lett 137:91-96.
Sloviter RS, Lowenstein DH (1992) Heat shock protein expression in vulnerable cells of the rat hippocampus as an indicator of excitationinduced neuronal stress. J Neurosci 12:3004-3009.

Sloviter RS, Valiquette G, Abrams GM, Ronk EC, Sollas A, Paul LA, Neubort SL (1989) Selective loss of hippocampal granule cells in the mature rat brain after adrenalectomy. Science 243:535-538.

Sloviter RS, Dean E, Sollas AL, Goodman JH (1996) Apoptosis and necrosis induced in different hippocampal neuron populations by repetitive perforant path stimulation in the rat. J Comp Neurol 366:516-533.

Stanfield BB, Trice JE (1988) Evidence that granule cells generated in the dentate gyrus of adult rats extend axonal projections. Exp Brain Res 72:399-406.

Sutula T, Cascino G, Cavazos J, Parada I, Ramirez L (1989) Mossy fiber synaptic reorganization in the epileptic human temporal lobe. Ann Neurol 26:321-330.

Tauck D, Nadler J (1985) Evidence of functional mossy fiber sprouting in hippocampal formation of kainic acid-treated rats. J Neurosci 5:1016-1022.

Van der Zee CE, Rashid K, Le K, Moore K, Stanisz J, Diamond J, Racine RJ, Fahnestock M (1995) Intraventricular administration of antibodies to nerve growth factor retards kindling and blocks mossy fiber sprouting in adult rats. J Neurosci 15:5316-5323.

Wang L, Strittmatter SM (1996) A family of rat CRMP genes is differentially expressed in the nervous system. J Neurosci 16:6197-6207.

Weiser HG, Engel JR, Williamson PD, Babb TL, Gloor P (1993) Surgically remediable temporal lobe syndromes. In: Surgical treatment of the epilepsies, 2nd Ed (Engel Jr J, ed), pp 49-63. New York: Raven.

Wuarin J, Dudek FE (1996) Electrographic seizures and new recurrent excitatory circuits in the dentate gyrus of hippocampal slices from kainate-treated epileptic rats. J Neurosci 16:4438-4448. 